INTER NATIONAL MONETARY FUND

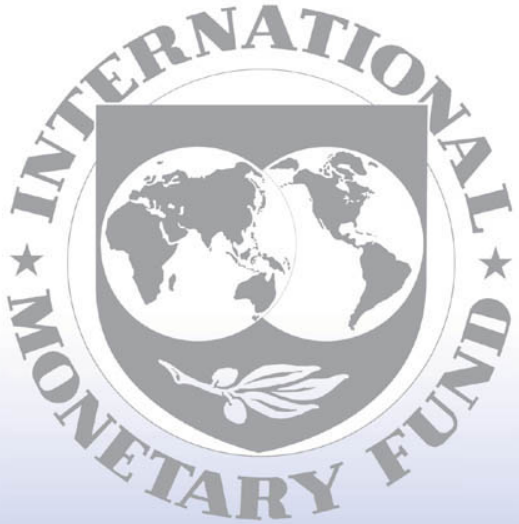

Staff

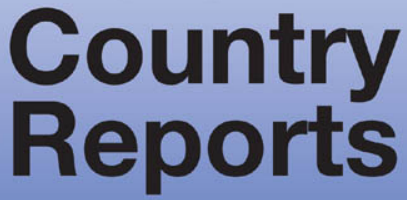




\section{Islamic Republic of Afghanistan: Selected Issues}

This Selected Issues paper for Islamic Republic of Afghanistan was prepared by a staff team of the International Monetary Fund as background documentation for the periodic consultation with the member country. It is based on the information available at the time it was completed on January 30 , 2008. The views expressed in this document are those of the staff team and do not necessarily reflect the views of the government of Islamic Republic of Afghanistan or the Executive Board of the IMF.

The policy of publication of staff reports and other documents by the IMF allows for the deletion of market-sensitive information.

To assist the IMF in evaluating the publication policy, reader comments are invited and may be sent by e-mail to publicationpolicy@imf.org.

Copies of this report are available to the public from

International Monetary Fund $\bullet$ Publication Services

700 19th Street, N.W. • Washington, D.C. 20431

Telephone: (202) $6237430 \bullet$ Telefax: (202) 6237201

E-mail: publications@imf.org • Internet: http://www.imf.org

Price: $\$ 18.00$ a copy

\section{International Monetary Fund Washington, D.C.}


This page intentionally left blank 


\section{INTERNATIONAL MONETARY FUND}

\section{ISLAMIC REPUBLIC OF AFGHANISTAN}

\section{Selected Issues}

Prepared by Mohamad Elhage, Mitra Farahbaksh, Jaroslaw Wieczorek (all MCD), Justin Tyson (FAD), and Magnus Saxegaard (PDR)

Approved by Middle East and Central Asia Department

January 30, 2008

Contents

I. Fiscal Sustainability Issues in Afghanistan: Coping with Security Pressures and

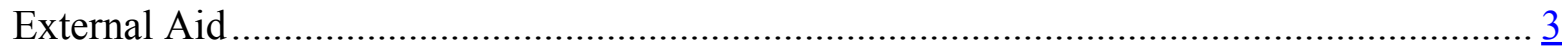

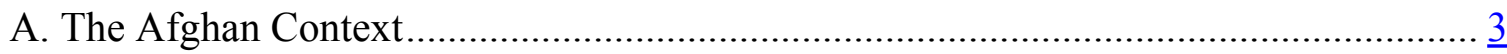

B. Defining Fiscal Sustainability: A Practical Approach ........................................... 4

C. Additional Considerations................................................................................... 7

D. Moving Towards Sustainability ....................................................................

II. Banking Sector Developments in Afghanistan ........................................................... 12

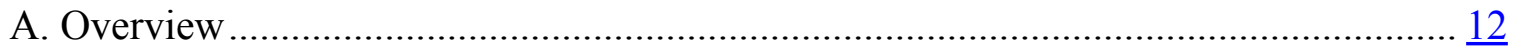

B. Recent Developments in the Financial Sector .................................................... 12

C. Financial Status of the Banking Sector ............................................................ 16

D. Legal Framework and Banking Supervision.................................................... 19

E. A Reform Strategy ................................................................................... 21

III. The Exchange Rate and the Conduct of Monetary Policy in Afghanistan .......................... 22

A. Introduction ............................................................................................ 22

B. The Monetary Policy Framework ..................................................................... 22

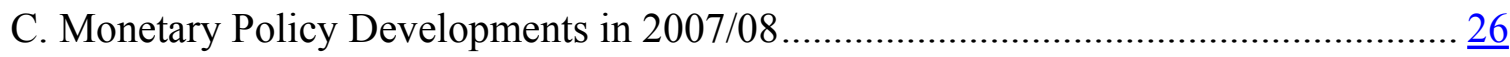

D. Conclusion and Summary of Recommendations .............................................. 29

Box

II.1 Da Afghanistan Bank's Self-Assessment Against the Basel Core Principles .....................20

Figures

I.1. Components of the Budget, 2007/08 f...................................................................

I.2. Domestic Revenue and Total Recurrent Government Expenditure, 2004/05-2012/13 ......... $\underline{6}$

I.3. Timing Revisions for Closing the Operating Budget Deficit, 2003/04-2012/13 .................

I.4. Breakdown of the 2007/08 Core Development Budget (YTD) ........................................

II.1. Banking Sector's Assets and Deposits, 2004/05-September 2007 .................................14 


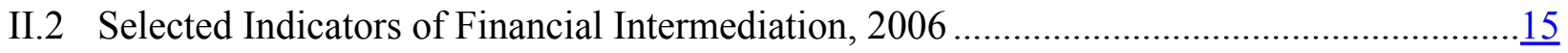

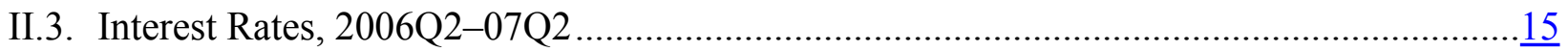

III.1. Simplified Flow-Chart of Cash Flows in Afghanistan ..................................................

III.2. Daily currency in Circulation and Nominal Exchange Rate, 2007/08 …...........................27

III.3. Daily DAB Foreign Exchange Auction Sales and Exchange Rate.......................................28

Tables

I.1. Revenue and Expenditure as a Percent of GDP in Selected LICs.......................................... $\underline{8}$

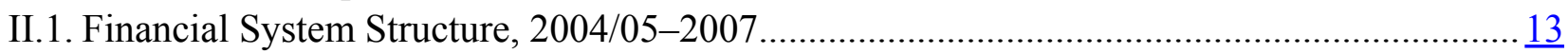

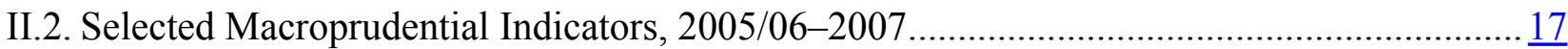

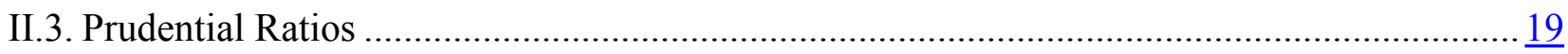




\section{Fiscal SustainabiLity IsSues In Afghanistan: COPING With SeCurity Pressures ANd EXTERnal AId ${ }^{1}$}

\section{A. The Afghan Context}

\section{Fiscal sustainability is one of several policy objectives that Afghanistan is} expected to achieve in the context of the PRGF-supported program. In the case of Afghanistan, post-war reconstruction needs, a low revenue base, and the impact of large inflows of external assistance on the economy give rise to a daunting set of challenges, which include:

- Maintaining macroeconomic stability, which may be a challenging in the presence of large donor-financed public spending;

- Achieving the twin objectives of growth promotion and poverty reduction. The government's approach in this regard is to increase productive expenditure and strengthen revenue, while creating an enabling business environment. At the same time, however, there is increasing political pressure to raise nonproductive expenditure and adopt distortive revenue measures;

- Encouraging private sector development, which may be affected by high levels of government and donor spending. First, public spending might drive up input costs for the private sector, such as the cost of skilled labor and construction. Second, large aid inflows may increase the overall role of the government in directing resources and controlling economic activity, thus reducing the space for private sector growth. ${ }^{2}$

2. The budget continues to have an expenditure structure that is heavily dependent on external funding. The components of the budget are the core and the external budget. The core budget is controlled by the government and can be divided into: (i) the core operating budget, consisting mainly of recurrent expenditure such as employee

\footnotetext{
${ }^{1}$ This paper was prepared by Justin Tyson. The paper builds on discussions with the authorities and the approach to fiscal sustainability set out in the World Bank's 2005 Public Expenditure Review (World Bank, 2005). It sets out the framework for analyzing fiscal sustainability under Afghanistan's PRGF arrangement agreed in June 2006.

${ }^{2}$ Foreign-financed government spending increases would also lead to slower credit growth to the private sector as the central bank seeks to control money supply growth. However, at present credit growth in Afghanistan is mainly constrained by other factors, including banking sector weaknesses.
} 
compensation, transfers, and outlays on goods and services; and (ii) the core development budget, which comprises largely donor-financed development projects and some recurrent costs. The external budget consists of direct donor expenditure that is approved and executed outside the national budget process; ex post reporting on this component is still weak (Figure I.1).

Figure I.1. Islamic Republic of Afghanistan: Components of the Budget, 2007/08

(In percent of GDP)

Type of Expenditure

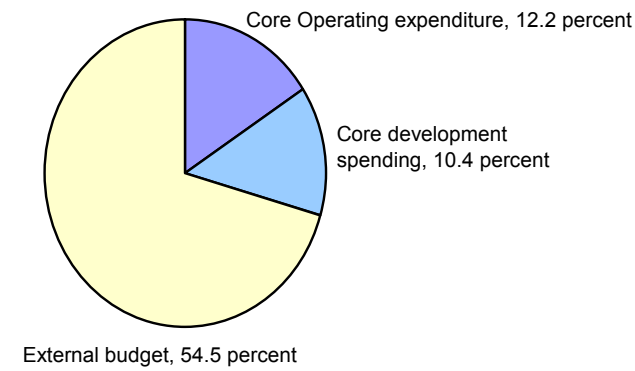

Source of

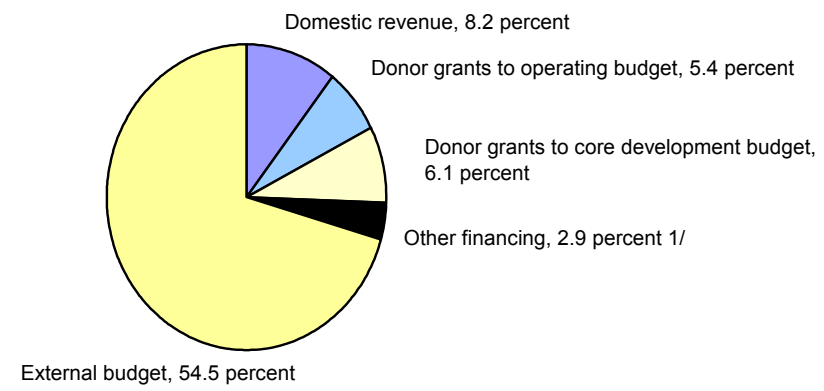

Sources: Ministry of Finance; Da Afghanistan Bank; donors; and Fund staff estimates.

$1 /$ Consists of external loans and use of government deposits.

\section{Ensuring that the overall revenue and expenditure profile is sustainable over} the medium to long term is a challenging task. Longer-term fiscal sustainability depends critically on the debt dynamics and the prospects for sustained concessional external financing. So far, the government has demonstrated a relatively prudent approach to fiscal policy by funding operating expenditure from domestic revenue and external grants. Nonetheless, the risk inherent in the large recurrent component of the external budget that is directly financed by donors warrants continued attention.

\section{B. Defining Fiscal Sustainability: A Practical Approach}

\section{Afghanistan does not fully fit into the traditional framework for analyzing fiscal} sustainability. While the term fiscal sustainability has various interpretations, the bulk of the literature focuses on whether current fiscal policy can be continued into the future without threatening government solvency. ${ }^{3}$ A common approach is to compare actual government

\footnotetext{
${ }^{3}$ Chalk and Hemming (2000).
} 
policy to a "baseline" primary deficit scenario that stabilizes the debt to GDP ratio. Yet, Afghanistan finances most of its fiscal deficit through external grants, and the small amount of borrowing it undertakes is on highly concessional terms; also, financing from Da Afghanistan Bank (DAB) is not an option. The HIPC and MDRI processes have significantly reduced the stock of debt, thus greatly improving the debt dynamics going forward. Moreover, the current high level of spending on reconstruction and security is not expected to continue indefinitely.

5. In any case, the present level of the core budget deficit before grants exposes Afghanistan's present fiscal vulnerabilities and highlights the need for a fiscal policy rooted on realistic assumptions. The overall core budget deficit before grants is forecast to average about 13 percent of GDP over the next five years. Were grants to fall short of projections, this would lead, in the absence of borrowing, to an automatic contraction in expenditure as many grants to the core budget are specifically linked to development projects. The situation would be even more difficult if grants to the external budget were cut, given that a large proportion of critical expenditure, including in the areas of health and security, takes place through the external budget. Fiscal sustainability implies that a country should not keep borrowing knowing that a major adjustment, or a remarkable pickup in growth, will be needed to be able to continue servicing its debt. ${ }^{4}$ In the case of Afghanistan, the government should be cautious about incurring long-term expenditure obligations knowing that major future cuts, or external support of an indefinite length and unrealistic proportions, will be needed to cover the deficit.

\section{The medium-term fiscal sustainability objective of the Ministry of Finance} (MOF) is to cover recurrent expenditure with domestic revenue sources. ${ }^{5}$ Recurrent expenditure represents the most basic cost of running the government and, therefore, should be covered by sustainable resources. A related indicator of fiscal sustainability is the ratio of domestic revenue to total estimated recurrent expenditure, including that in the external budget $^{6}$ (Figure I.2).

\footnotetext{
${ }^{4}$ See Baldacci and Fletcher (2004).

${ }^{5}$ This is often interpreted as covering the core operating budget with domestic revenue, even though the core development budget also includes some recurrent expenditure.

${ }^{6}$ A target ratio for this indicator of 58 percent by 2010/11 was set out in the Afghanistan Compact agreed between the authorities and donors in London in 2006.
} 
Figure I.2: Islamic Republic of Afghanistan: Domestic Revenue and Total Recurrent Government Expenditure, 2004/05-2012/13 (Percent of GDP)

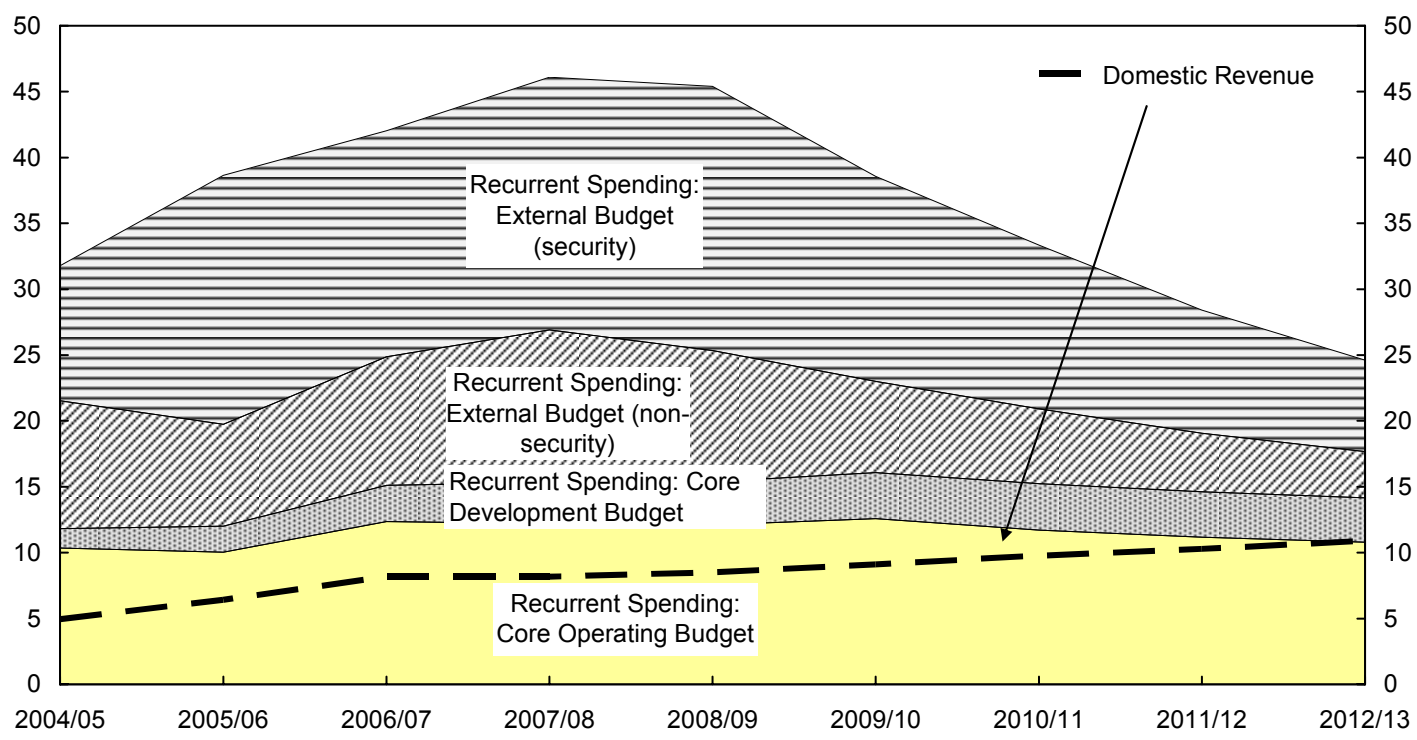

Sources: Government of Afghanistan; and Fund staff estimates.

\section{A zero operating budget balance serves as a suitable short- to medium-term}

fiscal anchor. The authorities use the timeline to achieving this objective as a practical and transparent indicator of changes to the medium-term fiscal outlook resulting from current decisions. The further out the target date for covering operating expenses with domestic revenue, the greater the risk that donor support will dwindle to a level that would compromise overall government expenditure and force expenditure cuts. Figure I.3 shows how the target date has moved since the Board approved Afghanistan's PRGF arrangement.

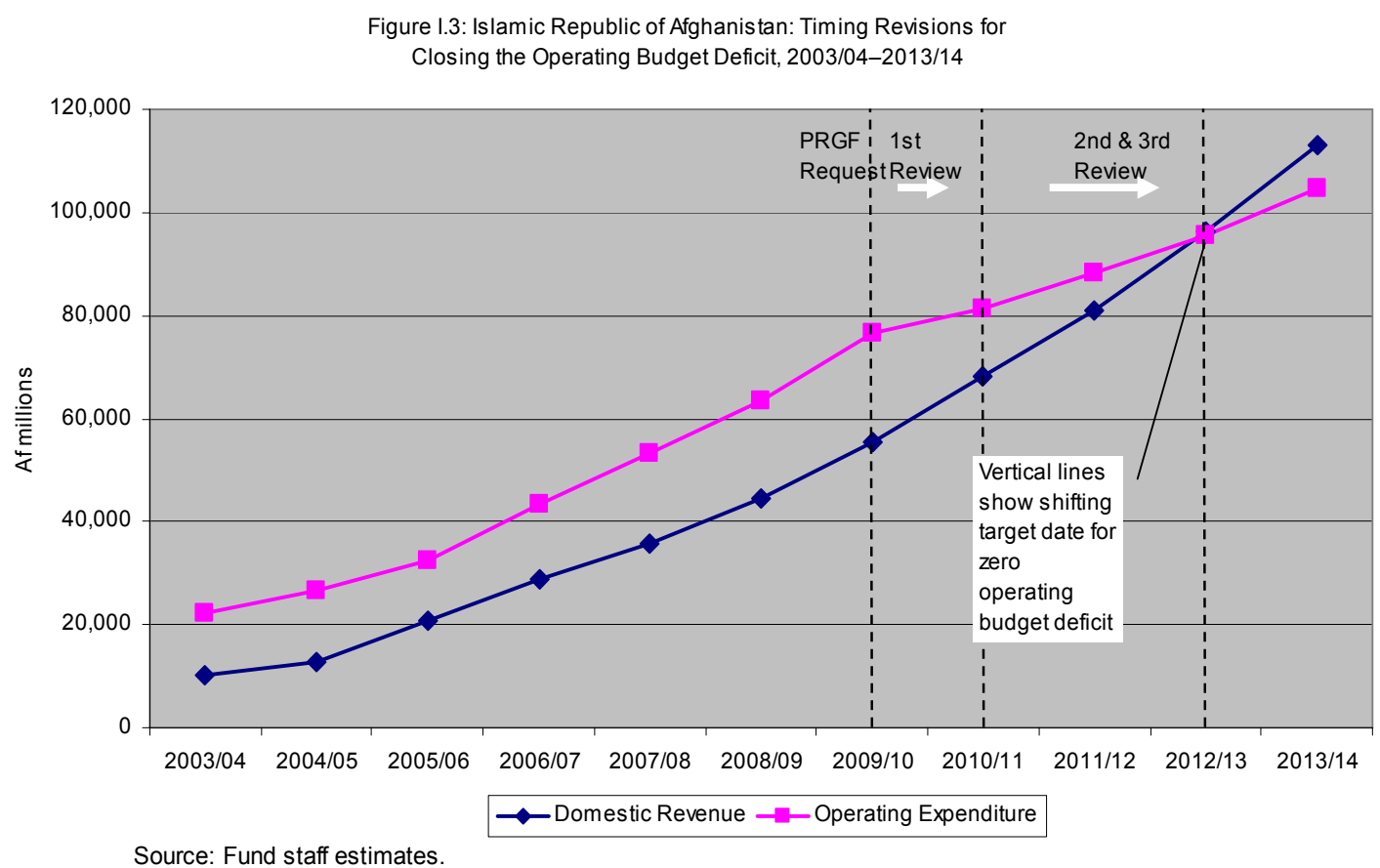

CInternational Monetary Fund. Not for Redistribution 


\section{Additional Considerations}

8. Using the Medium-Term Fiscal Framework (MTFF) to define a sustainable fiscal trajectory for Afghanistan will assist the authorities in measuring progress against a number of key policy objectives.

9. A sustainable expenditure path, together with a strong domestic revenue effort, will help manage the transition to self-reliance and policy autonomy. Large-scale donor support has been and remains indispensable, but has brought its own set of challenges. Donor dependency has: (i) complicated expenditure prioritization, as much of the donor-driven spending has not been properly coordinated with the national budget process and is characterized by weak reporting; and (ii) reduced the government's incentives to raise domestic revenue in a country with a historically weak performance in this area.

\section{It is important to smooth public expenditure through a well sequenced path.}

First, this will provide more certainty in resource availability to line ministries facilitating the planning of the delivery of core services, while avoiding spending increases beyond their absorptive capacity. Second, it will assist in managing the wide macroeconomic impact of government spending by improving predictability. Lastly, it will provide a framework for the government to gradually assume responsibility for expenditure obligations currently in the external budget. The growth in government expenditure should not only be based on the availability of revenue and donor assistance, but should also be consistent with a smooth path towards achieving the long-term fiscal objectives (paragraphs 6-7).

\section{Fiscal policy could include risk mitigation measures to better manage potential} aid volatility and avoid a painful fiscal adjustment. Given the high dependence on external aid, it would be prudent to consider both maintaining a buffer of deposits at the central bank and developing the domestic debt market, or contingent financing arrangements, over the medium term. The government currently has deposits with DAB amounting to 7.8 percent of GDP, ${ }^{7}$ however, these are projected to be drawn down gradually over the medium term to finance discretionary development expenditure in the core budget. A prudent level of deposits might be calculated as a function of the aid funded recurrent costs. However, aid volatility in Afghanistan is hard to measure, as year-on-year changes and the discrepancy between planned and actual grants over the last five years are as likely to reflect execution bottlenecks as availability. In addition to the deposit buffer, the government could rely on domestic borrowing to avoid painful expenditure cuts associated with aid shortfalls. However, such borrowing will need to be used cautiously in order to avoid unfavorable debt dynamics.

\footnotetext{
${ }^{7}$ DAB data on government deposits as of October 21, 2007.
} 


\section{Moving Towards Sustainability}

\section{Moving towards fiscal sustainability and coping with fiscal uncertainties} requires further enhancing domestic revenue mobilization. Afghanistan has the lowest ratio of domestic revenue to GDP among countries with PRGF-supported programs (Table I.1). It also has the lowest coverage of expenditure by domestic revenue among these countries. The authorities are addressing this issue through significant revenue mobilization efforts under Afghanistan's PRGF-supported program. As additional revenue is generated, it could be used to: (i) finance discretionary spending in the development budget; (ii) cover recurrent costs in the development budget; or (iii) set aside as a reserve to accommodate the future transfer of donor financed expenditures to the core budget.

13. The flexibility to deal with an unforeseen loss of resources and respond to the priorities emerging from the Afghanistan National Development Strategy (ANDS) can be enhanced by reducing expenditure rigidities. Moving rapidly towards operating budget autonomy will free domestic resources that could be used for reconstruction and capital expenditures, contributing to future economic growth. Moreover, the government should be cautious about financing recurrent expenditure programs, which are hard to compress, with volatile aid flows.

Table I.1. Islamic Republic of Afghanistan: Revenue and Expenditure as a Percent of GDP in Selected LICs

\begin{tabular}{|c|c|c|c|c|c|c|}
\hline \multirow[b]{2}{*}{ Year of PRGF } & \multicolumn{3}{|c|}{ Domestic Revenue } & \multicolumn{3}{|c|}{ Central Government Expenditure } \\
\hline & $1 \mathrm{st}$ & 2nd & $3 r d$ & $1 \mathrm{rst}$ & 2nd & $3 r d$ \\
\hline Afghanistan, Islamic Republic of & 8.2 & 8.2 & 8.5 & 21.5 & 22.6 & 23.0 \\
\hline Burkina Faso & 11.9 & 12.7 & 12.2 & 20.1 & 21.2 & 21.4 \\
\hline Burundi 1/ & 20.1 & 18.8 & 19.0 & 39.8 & 36.8 & 41.8 \\
\hline Guinea-Bissau & 16.0 & 16.3 & 16.4 & 34.1 & 39.4 & 37.6 \\
\hline Nepal $1 /$ & 12.3 & 12.2 & 12.9 & 16.0 & 15.5 & 16.5 \\
\hline Rwanda 1/ 2/ & 15.0 & 15.0 & 15.2 & 28.6 & 29.7 & 29.4 \\
\hline Sierra Leone 2/ & 12.5 & 13.2 & 13.4 & 21.4 & 25.3 & 27.3 \\
\hline Tajikistan 1/ & 16.5 & 15.0 & 17.3 & 19.2 & 19.2 & 20.3 \\
\hline Averages & 14.1 & 13.9 & 14.3 & 25.1 & 26.2 & 27.2 \\
\hline
\end{tabular}

Source: IMF staff estimates.

1/ Fiscal coverage is General Government. 2/ Initial program year 2006.

14. The composition of expenditure is also critical for managing the macroeconomic effects of government spending and moving towards fiscal sustainability. In particular, there is a need to adequately manage the future recurrent cost implications of capital spending in the core development and external budgets. The fiscal program already builds in assumptions regarding future operating and maintenance costs from existing capital projects 
in the core development budget, but this exercise needs to be undertaken more systematically as part of the annual budget process, including by explicitly linking the current operating and maintenance budget to last year's investment. This approach also needs to be extended to the external budget. In preparing the ANDS, the constraints imposed by the future recurrent implications of investment projects should also be carefully considered.

15. The government needs a strategy for absorbing into the core operating budget the recurrent costs in the core development and external budgets. Figure I. 4 shows the year-to-date breakdown of the core development budget in 2007/08 - with recurrent costs accounting for a significant proportion. However, not all these costs represent a long-term commitment for the government. In particular, the costs for contractor services may decline as local capacity in the line ministries increases. Thus, the authorities need to develop financial management capacity in the line ministries to be able to reduce these costs over the medium term.

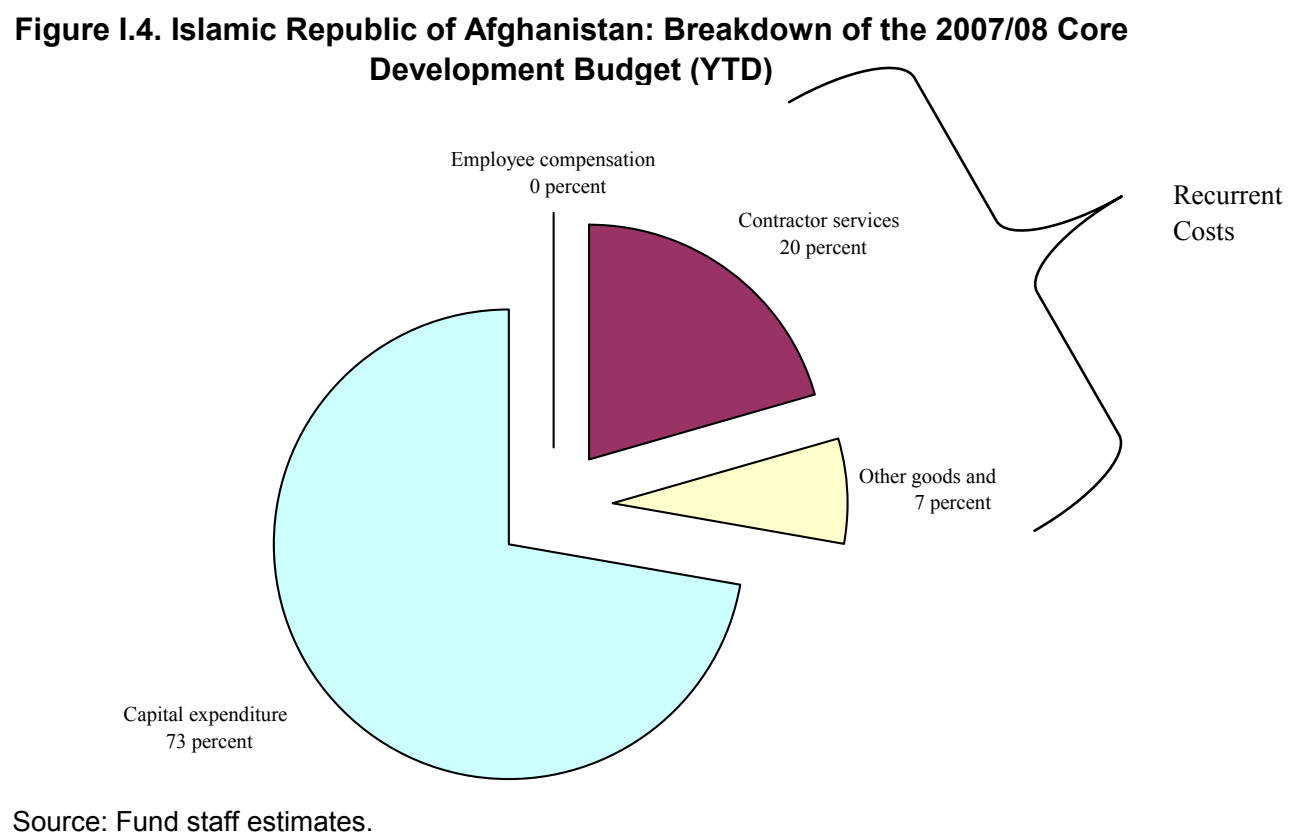

\section{Policy alignment and long-term donor financing commitments are effective} ways of reducing the risk associated with donor dependence. The external budget also has a large recurrent component, which highlights the importance of policy alignment and transparency over the costs that will eventually be assumed by the authorities. Any presumption of continued government funding for donor initiated projects should be explicitly agreed to beforehand. Long-term donor financing commitments would also allow better expenditure planning by reducing uncertainty. This, and the ability to plan and execute development projects in an efficient and cost-effective way, will be crucial for timing the transfer of direct-donor expenditures to the core budget. 


\section{Special attention should also be given to untangling future government}

obligations in the external security budget. The national police and the army are paid through the core budget. Yet, direct donor expenditures on the Afghan security forces and equipment are still estimated to be about half the external budget, or 26 percent of GDP, in 2007/08, with the bulk being recurrent expenditure. While this sector will need continued external support over the medium term, it is not clear that the cost of supporting the Afghan security forces will remain unchanged at current levels in the future.

18. Finally, there is a need to ensure that public expenditure focuses on the most productive areas, such as removing bottlenecks to private sector growth. This will help mitigate the detrimental effects on competitiveness of foreign aid inflows. The authorities' strategy in this regard needs to be informed by a coherent vision of the government's role in the economy. In the short term, security expenditures are likely to dominate and, in the Afghan context, could be seen as creating an enabling environment for private activities. Strong private sector growth will expand the government's revenue base and further reduce reliance on external support. 


\section{REFERENCES}

Baldacci, Emanuele and Kevin Fletcher, 2004, "A Framework for Fiscal Debt Sustainability in Low-Income Countries," Chapter 6 in Helping Countries Develop: The Role of Fiscal Policy, ed. By Sanjeev Gupta, Benedict Clements, and Gabriela Inchauste (Washington: International Monetary Fund).

Chalk, Nigel and Richard Hemming, 2000, "Assessing Fiscal Sustainability in Theory and Practice,” IMF Working Paper 00/81 (Washington: International Monetary Fund).

World Bank, 2005, Afghanistan: Managing Public Finances for Development, World Bank Report No. 34582-AF (Washington: World Bank). 


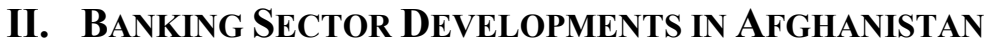

\section{A. Overview ${ }^{1}$}

\section{Since the fall of Taliban in 2001, Afghanistan has made considerable progress} in revitalizing its financial sector. The authorities have established a modern central bank, which is responsible for supervising the banking sector, and have put in place the main components of a legal framework that is in line with international standards. As a result, the banking institutions have improved their capacity as financial intermediaries and have grown substantially over the last couple of years. The rapid growth of the banking system broadened the range of financial services available to the private sector, but it also created challenges for the supervisory authorities. DAB is addressing these challenges through closer scrutiny of emerging vulnerabilities and capacity building with extensive donor support.

2. This chapter reviews developments in the banking sector and provides recommendations on how to address emerging vulnerabilities. Section B examines banks' balance sheets and the level of intermediation, while Section C discusses some key financial soundness indicators. Section D reviews developments in supervision and the banking sector's legal framework. Section E provides some recommendations.

\section{B. Recent Developments in the Financial Sector}

3. The financial system in Afghanistan consists of banks, foreign exchange dealers, microfinance institutions, and money service providers. As of end-2007, there were 16 licensed banks (compared with six banks in 2001), including three state-owned banks and five branches of foreign banks (Table II.1). Banks had 171 branches in 20 provinces. In addition to the formal banking sector, there are 311 foreign exchange dealers throughout the country, including 171 dealers in Kabul. Additionally, there are 89 licensed money service providers, and 8 more in the process of being licensed. Also, 14 microfinance institutions, including 12 nongovernmental organizations, provide financial assistance to small businesses. Finally, DAB has 75 branches, 14 of which are in Kabul. The vast majority of DAB's branches offer commercial banking services.

\footnotetext{
${ }^{1}$ This paper was prepared by Mitra Farahbaksh.
} 
Table II.1. Islamic Republic of Afghanistan: Financial System Structure, 2004/05-2007

\begin{tabular}{|c|c|c|c|c|}
\hline & $2004 / 05$ & $2005 / 06$ & $2006 / 07$ & Sep. 2007 \\
\hline \multicolumn{5}{|l|}{ Total number of: } \\
\hline Banks & 11 & 12 & 15 & 16 \\
\hline Private & 4 & 4 & 7 & 8 \\
\hline State-owned & 3 & 3 & 3 & 3 \\
\hline Foreign-owned subsidiaries & 4 & 5 & 5 & 5 \\
\hline & \multicolumn{4}{|c|}{ (In millions of U.S. dollars) } \\
\hline \multicolumn{5}{|l|}{ Assets } \\
\hline Banks & 388 & 614 & 1,081 & 1,318 \\
\hline Private & 82 & 238 & 629 & 789 \\
\hline State-owned & 212 & 226 & 224 & 229 \\
\hline Foreign-owned subsidiaries & 94 & 150 & 228 & 300 \\
\hline \multicolumn{5}{|l|}{ Deposits } \\
\hline Banks & 182 & 394 & 812 & 1,022 \\
\hline Private & 51 & 194 & 520 & 652 \\
\hline State-owned & 47 & 65 & 74 & 84 \\
\hline Foreign-owned subsidiaries & 84 & 135 & 218 & 286 \\
\hline & \multicolumn{4}{|c|}{ (In percent of total) } \\
\hline \multicolumn{5}{|l|}{ Assets } \\
\hline Banks & 100.0 & 100.0 & 100.0 & 100.0 \\
\hline Private & 21.1 & 38.8 & 58.2 & 59.9 \\
\hline State-owned & 54.6 & 36.8 & 20.7 & 17.4 \\
\hline Foreign-owned subsidiaries & 24.2 & 24.4 & 21.1 & 22.8 \\
\hline \multicolumn{5}{|l|}{ Deposits } \\
\hline Banks & 100.0 & 100.0 & 100.0 & 100.0 \\
\hline Private & 27.8 & 49.2 & 64.0 & 63.8 \\
\hline State-owned & 25.8 & 16.5 & 9.1 & 8.2 \\
\hline Foreign-owned subsidiaries & 46.4 & 34.3 & 26.8 & 28.0 \\
\hline \multicolumn{5}{|l|}{ Memorandum item: } \\
\hline Nominal GDP (in millions of U.S. dollars) & 5,402 & 6,487 & 7,048 & 8,719 \\
\hline
\end{tabular}

Sources: Da Afghanistan Bank; and Fund staff estimates. 
4. Afghanistan's banking system has been growing rapidly over the last few years. After a long period of slow growth, assets of the banking system more than tripled over the last couple of years, from \$388 million (7 percent of GDP) in March 2005 to $\$ 1.3$ billion (about 15 percent of GDP) in September 2007. This increase was mainly due to the expansion of private banks, whose share of the total assets of the banking system increased from 21 percent to 60 percent (Figure II.1). In fact, the assets of the two largest domestic private banks accounted for about 50 percent of banks' total assets in September 2007. Regarding the composition of assets, the ratio of banks' loan portfolios to total assets was 46 percent in September 2007, compared with only 15 percent in March 2005. On the liability side, banking sector deposits have grown almost five fold since March 2005, reaching about 78 percent of the consolidated banks' balance sheet (deposits plus capital) in September 2007.

Figure II.1. Islamic Republic of Afghanistan: Banking Sector's Assets and Deposits, 2004/05-September 2007
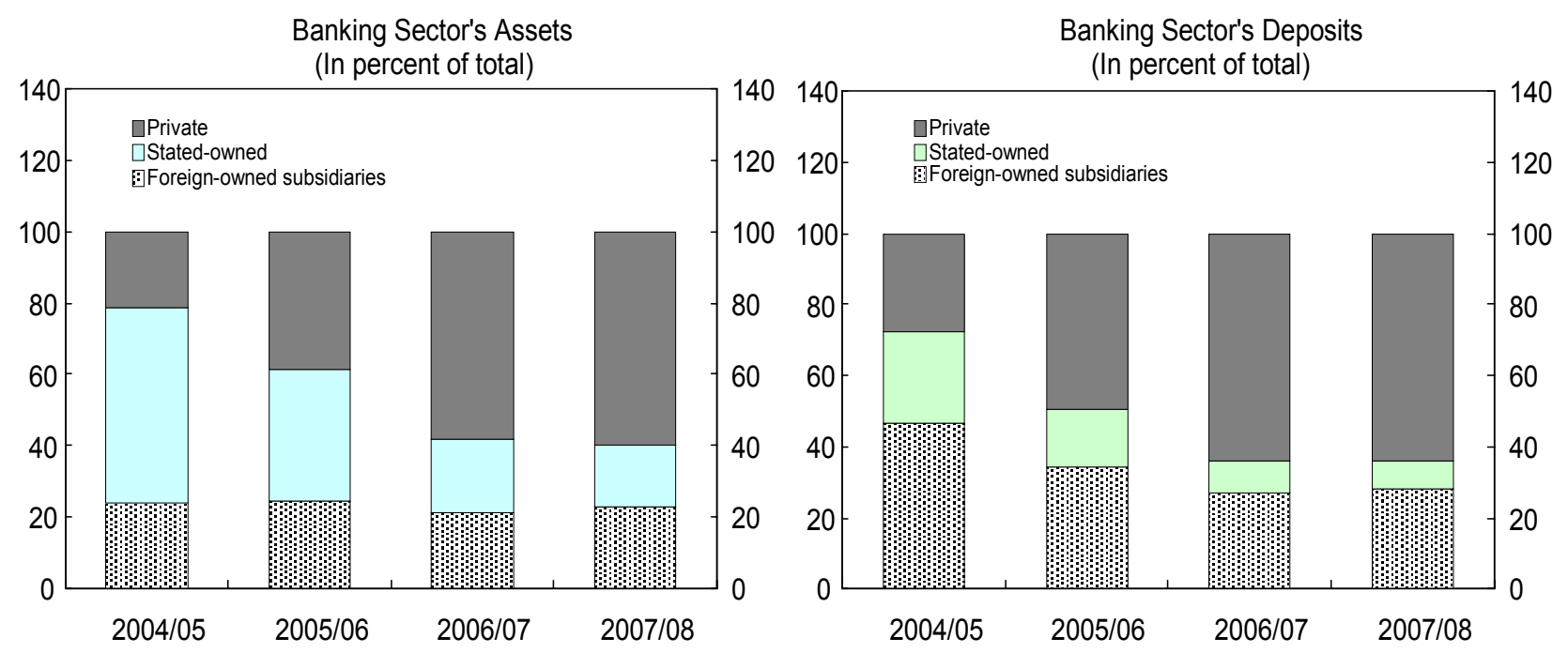

Sources: Da Afghanistan Bank (DAB); and Fund staff estimates.

5. Despite the rapid growth of the banking sector, financial intermediation remains relatively low. Indicators of financial depth, including bank credit to the private sector and deposits as a percent of GDP, remain well below those of neighboring countries (Figure II.2). 
Figure II.2. Islamic Republic of Afghanistan: Selected Indicators of Financial Intermediation, 2006

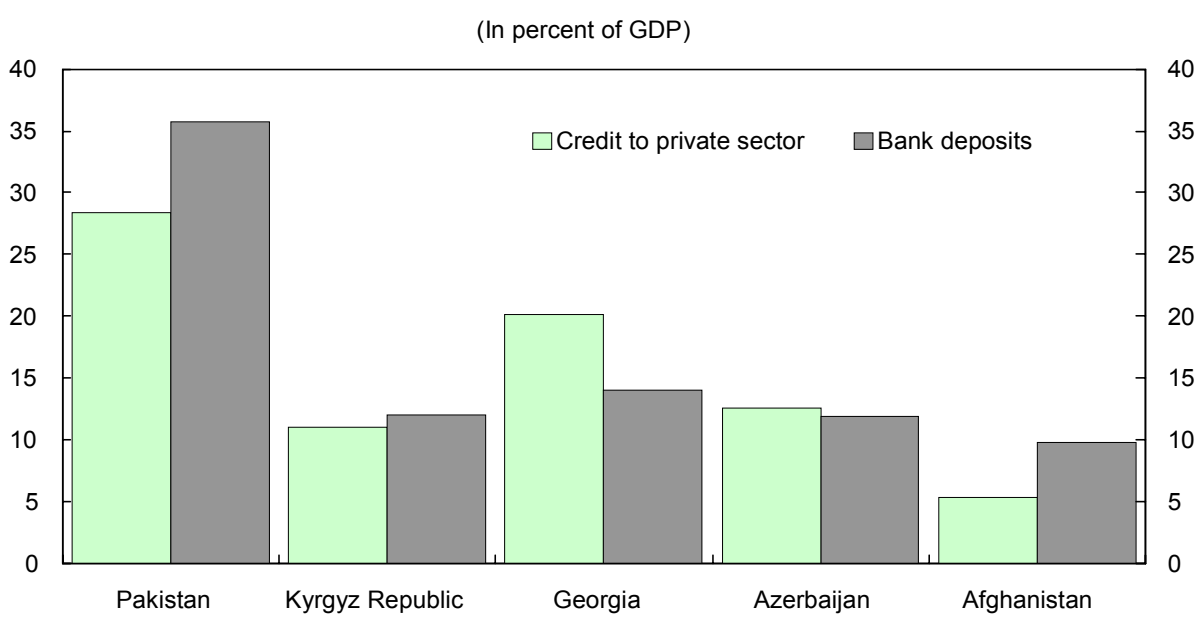

Sources: Data provided by the Afghan authorities; and Fund staff estimates.

6. The bulk of activities of the banking sector remains in foreign currencies. As of September 2007, about 77 percent of the total deposits and loans were denominated in U.S. dollars, a proportion slightly higher than in March 2005. Also, all interbank deposits were in foreign currencies, with 80 percent being denominated in U.S. dollars. About 35 percent of the deposit base of state-owned banks and 55 percent of their loans at end-September 2007 were denominated in U.S. dollars, indicating a currency mismatch for these banks. The deposit base of foreign banks' branches is mainly in U.S. dollars.

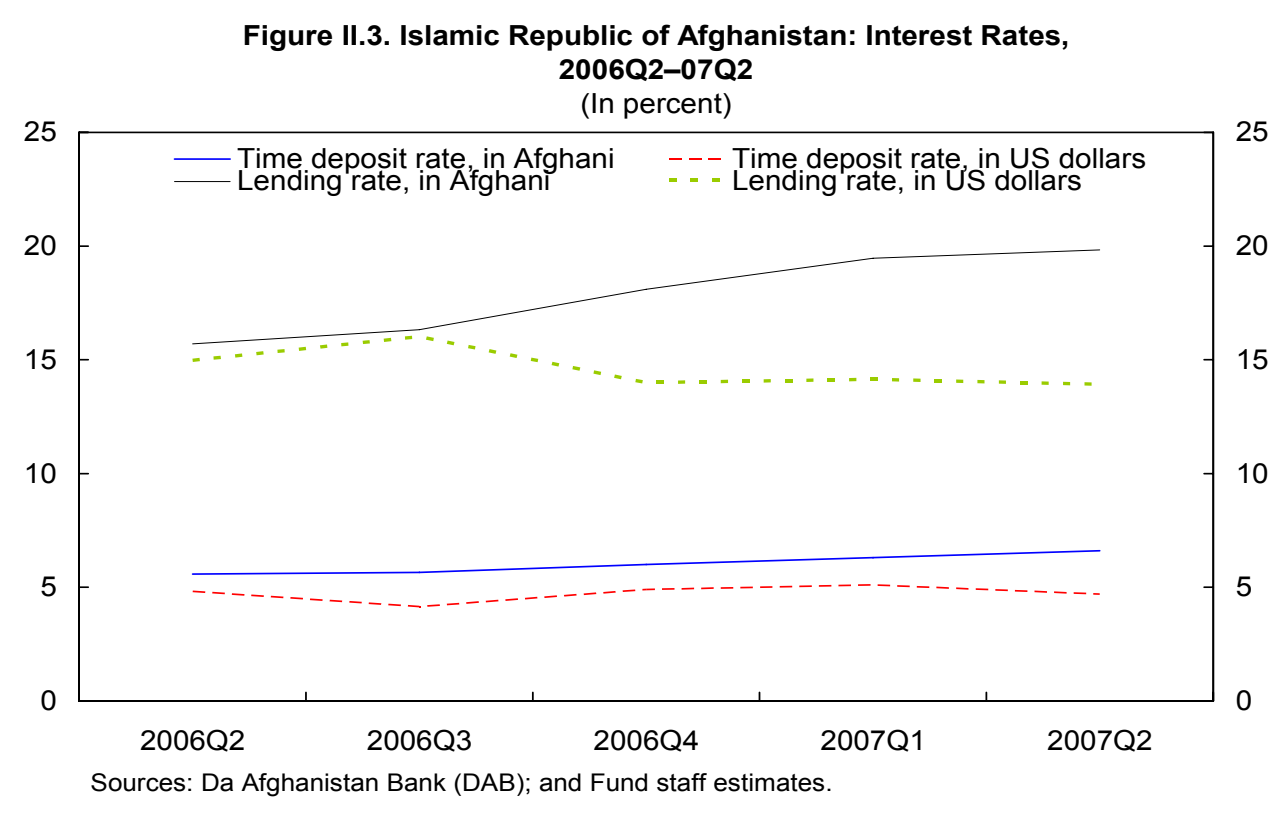


7. Interest rate spreads are wide, in part reflecting significant overhead costs. As of June 2007, the average Afghani lending rate was about 20 percent, while that on Afghani deposits was 7 percent (Figure II.3). The wide interest rate spread reflects the high cost of doing business in Afghanistan, the absence of an institutional infrastructure for obtaining credit information, and the lack of competition in the banking sector. ${ }^{2}$ It also reflects a weak credit culture and credit collection, lack of collateral, and insufficient bank capacity for proper credit assessment and risk management. Under these conditions, short-term credit continues to account for the bulk of bank lending.

\section{Only a small segment of the population has access to formal financial services.}

The lack of a core set of basic commercial laws, including mortgage, secured transaction, and commercial arbitration laws, prevents banks from providing credit to small- and medium-sized businesses. As a result, the formal banking sector in Afghanistan coexists with a large and vibrant informal financial sector, which has played an important role in both internal and external trade finance. The hawala dealers, major operators in the informal sector, offer a diverse range of services: money exchange, transfer of funds domestically and internationally, trade finance, microfinance, and limited deposit taking.

\section{Financial Status of the Banking Sector}

\section{DAB's on-site examination of banks has revealed considerable violations of} prudential regulations. These include violations related to lending to connected persons and open foreign exchange positions. Also, lending by some banks was found to be heavily concentrated in a few sectors, including the petroleum sector. Moreover, two state-owned banks had real estate holdings larger than allowed under the current regulations.

\section{Following on-site examinations, DAB is addressing the vulnerabilities that were} identified in a number of banks. Five banks, accounting for more than 60 percent of the assets of the banking system, were given a CAMEL rating of 4 on a scale of $1-5$ by DAB, while another 4 banks with total assets equivalent to about 15 percent of total banking sector's assets were given a rating of $3{ }^{3} \mathrm{DAB}$ has taken corrective actions in the case of the banks that are not complying with prudential regulations. These banks are monitored on a monthly basis and are subject to special targeted examinations.

\footnotetext{
${ }^{2}$ The bank concentration ratio is also high, with one bank accounting for two-thirds of total bank loans.

${ }^{3}$ CAMEL stands for Capital, Asset Quality, Management, Earnings, and Liquidity. The system uses a five-point scale for grading each category. An overall composite rating is also assigned based on the same scale, with 1 being the highest rating and 5 the lowest. Two newly charted banks with assets equivalent to 2 percent of the total were not assigned ratings.
} 


\section{Capital}

11. As of end-September 2007, the banking system was well capitalized, with an average capital adequacy ratio of 32 percent well above the statutory requirement of 12 percent (Table II.2). However, there is considerable variation across individual banks. In particular, some systemic private banks that have recently experienced significant growth in their loan portfolios have seen a drop in their capital adequacy ratios below the regulatory norm on a few occasions. The financial capital of all banks is well above the minimum required level of $\$ 5$ million.

Table II.2. Islamic Republic of Afghanistan: Selected Macroprudential Indicators, 2005/06-2007

(In percent, unless indicated otherwise)

\begin{tabular}{lrrr}
\hline & $2005 / 06$ & $2006 / 07$ & Sept. 2007 \\
\hline Total classified and watch credit/total regulatory credit 1/ & & & \\
Total classified credit (net of provisions)/tier 1 capital & 2.7 & 1.9 & 2.8 \\
Nonperforming loans to gross loans & 3.3 & 4.0 & 2.8 \\
Total capital/risk-weighted assets & 2.4 & 3.0 & 1.0 \\
Tier 1capital/risk-weighted assets & 37.0 & 55.0 & 32.0 \\
\hline
\end{tabular}

Source: Da Afghanistan Bank (DAB).

1/ Classified credit includes substandard, doubtful and loss.

12. The rapid growth of some private banks requires additional capital. Part of the additional capital should have been secured through profits. However, high fixed and security costs and ambitious branch expansion plans have limited banks' earnings. On some occasions, sufficient capital was either not provided or provided with a lag, resulting in some banks not meeting the minimum capital adequacy requirements.

13. Provisioning appears to be insufficient. Banks are often reluctant to provision, since intermediation margins are too low to cover additional provisions. 


\section{Asset classification}

\section{As of end-September 2007, the ratio of classified and watch loans to total loans} was 4.6 percent. This ratio is relatively low because it appears to reflect mainly the widespread practice of rolling over unsecured overdraft loans. In fact, only when the amount outstanding exceeds the facility limit, would a bank move loans to the classified category. If the limit is increased on review, then the point at which the balance outstanding becomes at risk is simply deferred. Moreover, DAB's classification of assets is mainly based on a single criterion of past due days, rather than on several criteria that are listed in the regulations and are necessary to appropriately judge risks.

15. Banks do not have sufficient experience in credit assessment. Often, credit is provided without collateral to customers who lack experience of a business relationship with financial institutions. Frequently, borrowers are not in a position to provide financial statements and cash flow forecasts, which would enable banks to assess and monitor their creditworthiness. Moreover, the assets of some banks are highly concentrated in a few industries, such as the petroleum sector (over 30 percent of private banks' loans). Also, exposure to start-up companies and borrowers whose primary business activities are outside Afghanistan is high.

\section{Management}

\section{On-site examination of banks has revealed weaknesses in some banks'} management, suggesting that corporate governance remains a significant problem.

\section{Earning}

17. On aggregate, banks appear to be profitable, although, as noted above, profit margins are relatively modest. Total net profits of the sector amounted to Af 2.7 billion in the first nine months of 2007, with an annualized return on assets of 1.75 percent. The main component of banks' income is interest income, accounting for 45 percent of total income as of September 2007. As of that date, the ratio of total expenses to total income was 49 percent.

\section{Liquidity}

18. As of September 2007, all banks complied with the 15 percent minimum broad liquidity ratio requirement (i.e., liquid assets as a percentage of attracted funds). In fact, the banking sector had excess liquid assets, which is attributable to deposit volatility. Some private banks have relied extensively on volatile non-interest-bearing accounts, where the remuneration consists of the right to participate in a draw for a reward. While DAB has encouraged banks to secure more conventional forms of deposits, a significant proportion of deposits remains in this "lottery" form, which increases volatility. 


\section{Legal Framework and Banking Supervision}

19. Banking supervision has improved but enforcement remains weak (Table II.3). DAB conducts regular on-site full examinations. These are followed by targeted examinations when weaknesses are identified and action plans to address them are drawn up. However, while DAB initially takes appropriate action, enforcement remains limited, and partial compliance is not followed up with more severe measures. Instead, banks are given more time to comply, while the timing of the next full scope examination is accelerated.

Table II.3. Islamic Republic of Afghanistan: Prudential Ratios

\begin{tabular}{ll}
\hline \multicolumn{1}{c}{ Requirements } & \multicolumn{1}{c}{ Quantitative Inidcators } \\
\hline Minimum capital requirment & $\$ 5$ million, equivalent to Af 250 million (must be held in Afghani) \\
Capital adequacy ratio & 12 percent \\
1st tier capital to risk-weighted assets & 6 percent \\
Limit on lending per borrower or group & 15 percent of regulatory capital \\
Total amount of all large loans issued by a bank & 100 percent of regulatory capital \\
Limit on lending to connected parties & 15 percent of regulatory capital \\
Liquidity ratio & 1. Quick liquidity ratio: highly liquid /volatile liquid $=20$ percent \\
& 2. High liquidity ratio: liquid assets as a percent of sum of \\
& attracted funds and designated off-balance sheet items. \\
Ceiling on open foreign exchange position & 40 percent of regulatory capital for all currency \\
& 20 percent of regulatory capital for one currency \\
\hline
\end{tabular}

Source: Da Afghanistan Bank (DAB).

\section{DAB has recently completed a self-assessment against the Basel Core Principles}

for Effective Bank Supervision. The assessment indicated that DAB is in substantive compliance with most of the Principles. It also yielded a roadmap for addressing deficiencies (Box II.1). 


\section{Box II.1. Da Afghanistan Bank's Self-Assessment Against the Basel Core Principles}

DAB completed an assessment of banking supervision using the Basel Core Principles (2006) in November 2007. The areas that were identified as being materially noncompliant included:

Principle 5: Major acquisitions. Require DAB notification of "significant" asset and investment acquisitions, including foreign bank holdings; specify prior approval requirements and criteria; require post acquisition notification for banks and nonbanks when deemed not "significant" per a defined capital threshold; and clarify reference to regulatory language concerning agreement for supervisory cooperation between cross-border supervisors of bank and nonbank entities.

Principle 7: Risk management process. Require minimum standards, risk parameters and measurement processes for all risk categories, i.e. credit, interest rates, liquidity, price, foreign exchange, transaction, compliance, reputation and strategic risks; require models in use by a bank to be periodically validated; require introduction of new products and services to be guided by adequate policies and control procedures; and require risk evaluation, monitoring, and control or mitigation functions to be clearly segregated from risk-taking functions in the bank.

Principle 12: Country and transfer risks. Modify regulation to include instructions on obtaining and reviewing sufficient and timely information on country risk and transfer risk by individual banks; provide guidance on minimum qualitative monitoring processes and application of counterparty measures employing risk based methodology; and provide requirements for specific provisioning against changing conditions within countries.

Principle 13: Market risk. Amend regulations providing for bank limits in all identified market risk instruments; and require appropriate policies, procedures, internal controls, administrative expertise and reporting processes in place before a bank engages in any market risk instrument transaction. Develop appropriate examination procedures to comply with regulation changes and provide necessary training to supervision staff.

Principle 15: Operational risk. Implement regulations specifically governing operational risk issues inclusive of bank policies and procedures governing technology, outsourcing, and litigation risk. Expand examination procedures appropriately and develop training processes to ensure adequate expertise and coverage of highly technical specialty areas.

Principle 16: Interest rate risk. Develop an interest rate risk regulation that includes minimum standards for interest rate risk management, i.e., policy, strategy, measurement processes inclusive of capital ratio analysis, and ensures that risk management responsibilities and risk-taking responsibilities are segregated.

Principles 24 and 25: Consolidated supervision. A formal agreement with cross-border supervisors is drafted but needs to be authorized by $\mathrm{DAB}$ and distributed to foreign regulators for their endorsement. DAB needs to alert domestic banks of the cooperative arrangements. DAB needs to enact regulation establishing a framework for minimum level and frequency of information to be shared while preserving confidentiality, and expand examination procedures to assess and verify consolidated information, the consolidated financial condition of foreign banking entities, and the quality of supervisory support provided by home/host regulators. 


\section{E. A Reform Strategy}

21. There is a need to develop a comprehensive financial sector strategy aimed at deepening financial intermediation and reducing key vulnerabilities. This strategy should also include a timetable for spinning off commercial activities of DAB and completing the restructuring of state-owned banks.

22. DAB needs to focus on banks' exposure to risks. As noted above, credit risk is the main source of vulnerability in the banking system, and the loan portfolio is highly concentrated in a few borrowers and sectors. Failure to comply with prudential regulations must be dealt with expeditiously. Also, banks need to enhance their capacity to analyze credit risk.

23. DAB should strengthen the enforcement of prudential regulations. The current form of 'prompt corrective action' needs to be strengthened by a system of trip wires which would automatically set off a supervisory response. Fines on the banks or on specific individuals for each day they fail to comply with a DAB order should be introduced. A degree of automaticity in enforcement actions would reduce the scope for political and other undue influence being brought to bear on the supervisors.

\section{Expansion of weak banks - those with CAMEL ratings of $\mathbf{4}$ and 5 -needs to be}

limited. The authorities have started placing limits on the expansion of weak banks by restricting their credit growth to 5 percent per quarter and suspending the issuance of licenses for new branches. These measures will be in effect until the relevant banks' CAMEL ratings are reassessed to be less than 4 .

25. The legal framework needs to be strengthened further. As noted above, the self-assessment report should provide a roadmap for addressing areas where DAB is not fully compliant. DAB has already strengthened the legal framework by issuing regulations on credit-granting standards and the credit-monitoring process, and on setting limits on sectoral loan concentration. Finally, a core set of basic commercial laws, including mortgage, secured transactions, and commercial arbitration laws is needed in order to reduce credit risks and allow banks to increase lending to small and medium-sized businesses, thereby reducing the size of the informal sector. 


\section{The Exchange Rate And the Conduct of Monetary Policy in Afghanistan ${ }^{1}$}

\section{A. Introduction}

1. During the last five years, Afghanistan has made significant progress towards a stable macroeconomic environment. In 2006/07 inflation declined to single digits, and since then the nominal exchange rate has been broadly stable despite large aid inflows. Improvements in the ability of DAB to effectively conduct monetary policy have been an important contributing factor to this progress, and since mid-2005 they have been a focal point for Fund technical assistance (TA).

2. The aim of this paper is to analyze the conduct of monetary and exchange rate policy in Afghanistan. Section B provides a brief summary of the operational framework for monetary policy, while Section C looks at the implementation of monetary policy over the past year. Section D presents conclusions and a summary of recommendations.

\section{B. The Monetary Policy Framework}

3. The 2003 central bank law states that the primary objective of monetary policy in Afghanistan is to maintain domestic price stability. As a secondary objective, DAB aims to foster the proper functioning of the financial system and promote a sound national payment system. Operationally, DAB has been maintaining price stability by basing its policy decisions on a growth rate target for currency in circulation $(\mathrm{CiC})$. When consistent with its target for $\mathrm{CiC}, \mathrm{DAB}$ has also aimed at smoothing short-term exchange rate fluctuations, given the large impact such fluctuations can have on inflationary expectations and inflation itself. Monthly targets for $\mathrm{CiC}$, consistent with the ceiling on $\mathrm{CiC}$ agreed on in the context of the PRGF-supported program, are set on the basis of expected real GDP growth, the velocity of $\mathrm{CiC}$, the target for inflation, and seasonal variations in the demand for liquidity.

\section{A high degree of substitutability between Afghanis and U.S. dollars appears to} be a key characteristic of the Afghan economy. As pointed out by Agénor and Montiel (1999, p. 105) currency substitution - the process whereby foreign currency substitutes for domestic money as a store of value, unit of account, and medium of exchange - has become a pervasive phenomenon in many developing countries. After several years of instabilitywhen the authorities raised the majority of their revenue from money creation and foreign currency was preferred to domestic currency - confidence in the Afghani appears to have increased to a point where there is indifference (at least for transaction purposes) between the

\footnotetext{
${ }^{1}$ This paper was prepared by Magnus Saxegaard.
} 
Afghani and some other currencies, notably the U.S. dollar and the Pakistani rupee. In fact, it seems probable that the elasticity of substitution between domestic and foreign monies is higher in Afghanistan than in other countries. ${ }^{2}$

\section{DAB conducts monetary policy primarily through interventions in the foreign} exchange market, but also through the sale/purchase of domestic securities (capital notes). Open-market operations (OMO) in foreign currency and in domestic securities affect base money. In countries with managed floats and more developed financial systems, it is common for the central bank to rely on foreign exchange interventions to meet its foreign reserve objectives, and on OMO in domestic securities to achieve base money or short-term interest rate operational targets. In Afghanistan, however, the market for capital notes (CNs) is still too thin for CNs to become the primary instrument of monetary policy, and DAB has been unwilling, until recently, to expand the CNs volume because of concerns about the associated higher interest costs. Currently, DAB aims to sell up to Af 400 million worth of 28-day notes and up to Af 100 million worth of 182-day notes in weekly auctions. ${ }^{3}$ This compares with average weekly sales of foreign exchange of US $\$ 18$ million (equivalent to approximately Af 900 million) in the foreign exchange auctions to date in 2007/08. DAB also operates standing credit and deposit facilities and maintains a reserve requirement for commercial banks.

\section{The conduct of foreign exchange auctions has undergone substantial changes,} in line with the recommendations of successive TA missions. Until mid-2005, weekly auctions were only open to Kabul-based nonbank foreign exchange dealers and were conducted using an open-outcry process, where dealers responded to an exchange rate proposed by DAB. Bids at the auction were settled over the three following days. Banks were excluded from auctions, but they were allowed to trade foreign exchange directly with the central bank at a price involving a relatively high spread. This setup not only encouraged collusion among dealers, but also discouraged genuine price discovery and made the process of deciding how much foreign exchange to sell-especially in the event of a trade-off between the $\mathrm{CiC}$ target and exchange rate volatility - unclear to both the market and the senior management of DAB. At present, foreign exchange auctions, which take place twice a week, are conducted as a first-price sealed bid auction with a two-day settlement period, as

\footnotetext{
${ }^{2}$ A formal evaluation of the importance of currency substitution in Afghanistan relative to other countries is the subject of a forthcoming Working Paper.

${ }^{3}$ Since late December 2007, DAB has doubled the issuance of CNs in primary auctions. Interest rates on CNs, which were previously below 10 percent, increased to 11-12 percent in January 2008.
} 
in most other countries. They have also been broadened to include foreign exchange dealers in the provinces as well as commercial banks. In addition, the secondary objective of smoothing out exchange rate fluctuations has been formalized. DAB manages the foreign exchange auctions to avoid exchange rate movements in excess of \pm 5 basis points from the previous auction, when this does not imply unacceptable departures from the $\mathrm{CiC}$ target.

\section{Currency substitution undermines the effectiveness of foreign exchange auctions} as a tool of monetary policy. Because of currency substitution, the quantity of money which matters for transaction purposes also includes those foreign monies that are close substitutes to Afghanis. As a result, interventions by the central bank through foreign exchange auctions change the currency composition of the stock of money, not its overall size. This implies that the impact of foreign exchange auctions may be limited. This supports the need to develop a more effective instrument of monetary policy, such as CNs to affect overall liquidity.

\section{Significant improvements have taken place in the capital notes program since its} inception in late 2004. The 1-day capital notes have been replaced by a standing deposit facility for banks, while 30 -day notes have been supplemented by 56 -days notes. This maturity structure was modified again in March 2006 with the introduction of 28-day notes to facilitate refinancing and reinvestment, and 182-day notes in early 2007 to encourage secondary trading and the development of a yield curve. At the same time, DAB moved to the more typical structure of capital notes as zero coupon, rather than interest-bearing bills, to facilitate price calculation, especially for secondary market trades. The stock of outstanding capital notes rose from Af 0.4 billion at end-2005 to Af 2.5 billion as of January 1, 2008, in line with increased interest among commercial banks, although the large amounts of overnight deposits and low interest rates on capital notes (slightly negative in real terms) suggest that the market can absorb higher amounts of capital notes.

\section{The implementation of monetary policy has also benefited from improvements} in DAB's ability to forecast liquidity, although further progress is necessary. In a largely cash-based economy, where the government and other major entities such as the U.S. Army and NGOs rely primarily on transfers from abroad for funding, being able to forecast accurately the autonomous factors affecting the central bank's balance sheet—such as spending by the donor community and the government - is crucial for accurately forecasting liquidity. Figure III.1 provides a stylized flow-chart of cash flows in Afghanistan. Liquidity forecasts have been improved to take into account projected liquidity injections by the MOF and the U.S. military. However, liquidity forecasts do not take into account government spending in the development budget, and the coverage of spending by donors and NGOs remains weak. 


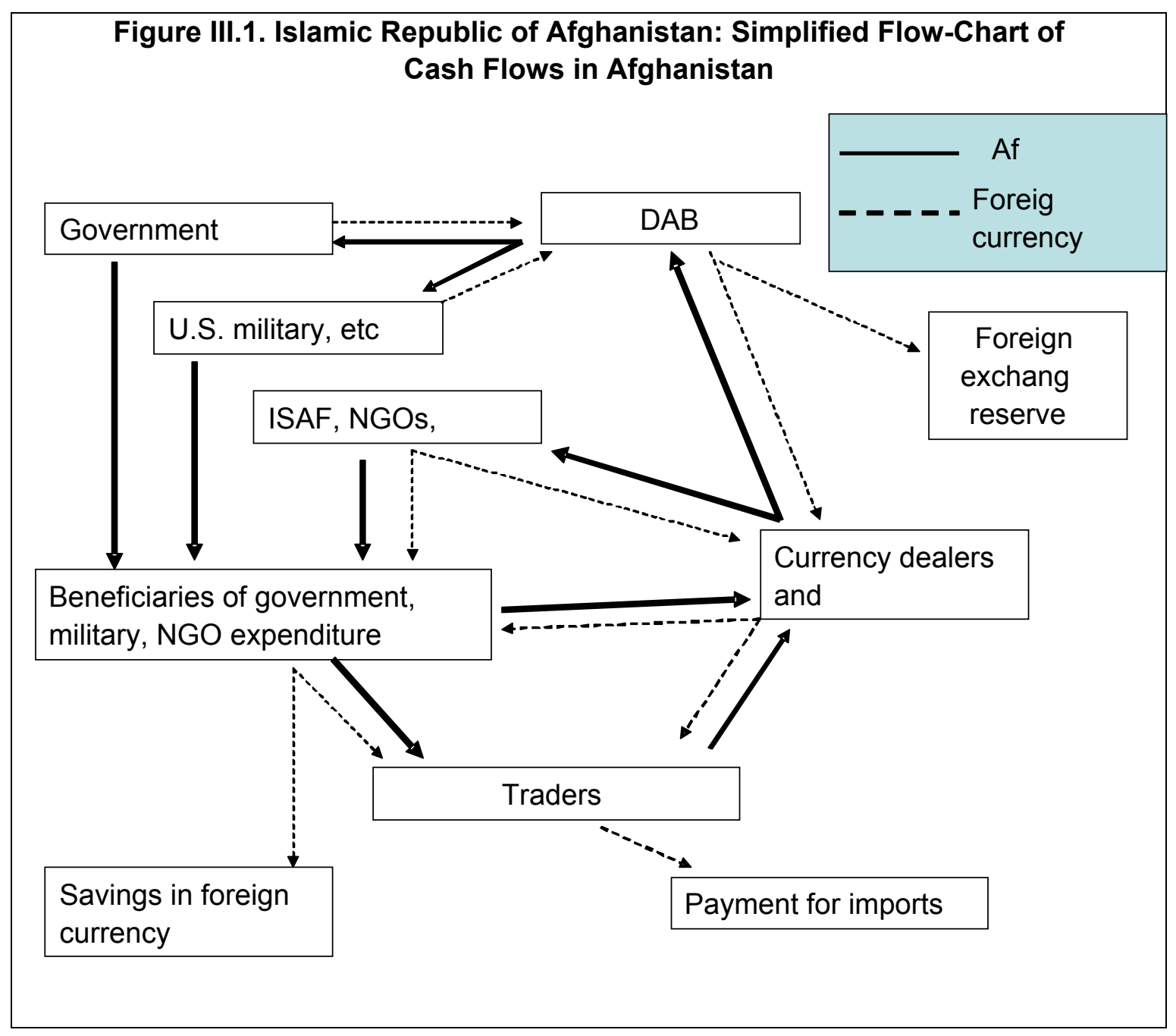

10. Further reforms to the foreign exchange auctions are needed to improve the effectiveness of monetary policy. Although they have been opened up to commercial banks, auctions continue to be dominated by foreign exchange dealers. For DAB this is inefficient, as it requires interacting with a relatively large number of small foreign exchange dealers who typically settle their bids in cash and in numerous tranches, rather than with a relatively small number of commercial banks that could use their accounts at the central bank. It also reduces transparency, given the authorities' limited oversight over foreign exchange dealers. ${ }^{4}$ To address these issues, DAB should foster the development of the wholesale foreign exchange market.

\footnotetext{
${ }^{4}$ Some progress has been made in licensing Hawalla dealers, who are now expected to report their operations by using forms that have been developed for purposes of combating money laundering and financing of terrorism.
} 
11. The effectiveness of monetary policy would also benefit from significantly increasing the volume of CNs. The outstanding volume of CNs as of January 1, 2008 (Af 2.5 billion) is insufficient to have an impact on $\mathrm{CiC}$, as they have been settled using banks' excess reserves. As a result, DAB has been unable to employ CNs as an effective tool of monetary policy. Increasing the volume of outstanding CNs would help overcome this problem and would improve the effectiveness of monetary policy.

\section{Developments in financial intermediation and liquidity forecasting suggest that} there may be scope to consider moving to base money as the primary operational target. The choice of $\mathrm{CiC}$ as the primary operational target for monetary policy reflects DAB's inability to monitor broader monetary aggregates. This problem is related to the rapid growth of, and lack of timely data on, the financial sector in Afghanistan. While CiC can be controlled directly by DAB, it has the drawback that its link to DAB's ultimate target, inflation, is relatively weak. This is true not only because of the rapid increase in financial intermediation but also because of currency substitution. Recent improvements in liquidity forecasting may allow DAB to move to an operational target more closely related to inflation, such as base money.

\section{Monetary Policy Developments in 2007/08}

\section{The conduct of monetary policy in Afghanistan in $2007 / 08^{5}$ can be divided into} five distinct periods, which yield useful insights into the challenges being faced by DAB. For 2007/08, DAB's target growth rate for CiC is 15.2 percent, compared to a ceiling under the PRGF-supported program of 19.0 percent. DAB's target for CiC assumes a broadly stable nominal exchange rate and incorporates the information available on seasonal variations in money demand. The evolution of $\mathrm{CiC}$ until end-November 2007 and the forecast for the remainder of the year, together with movements in the daily exchange rate, are depicted in Figure III.2.

\footnotetext{
${ }^{5}$ Until end-November 2007.
} 


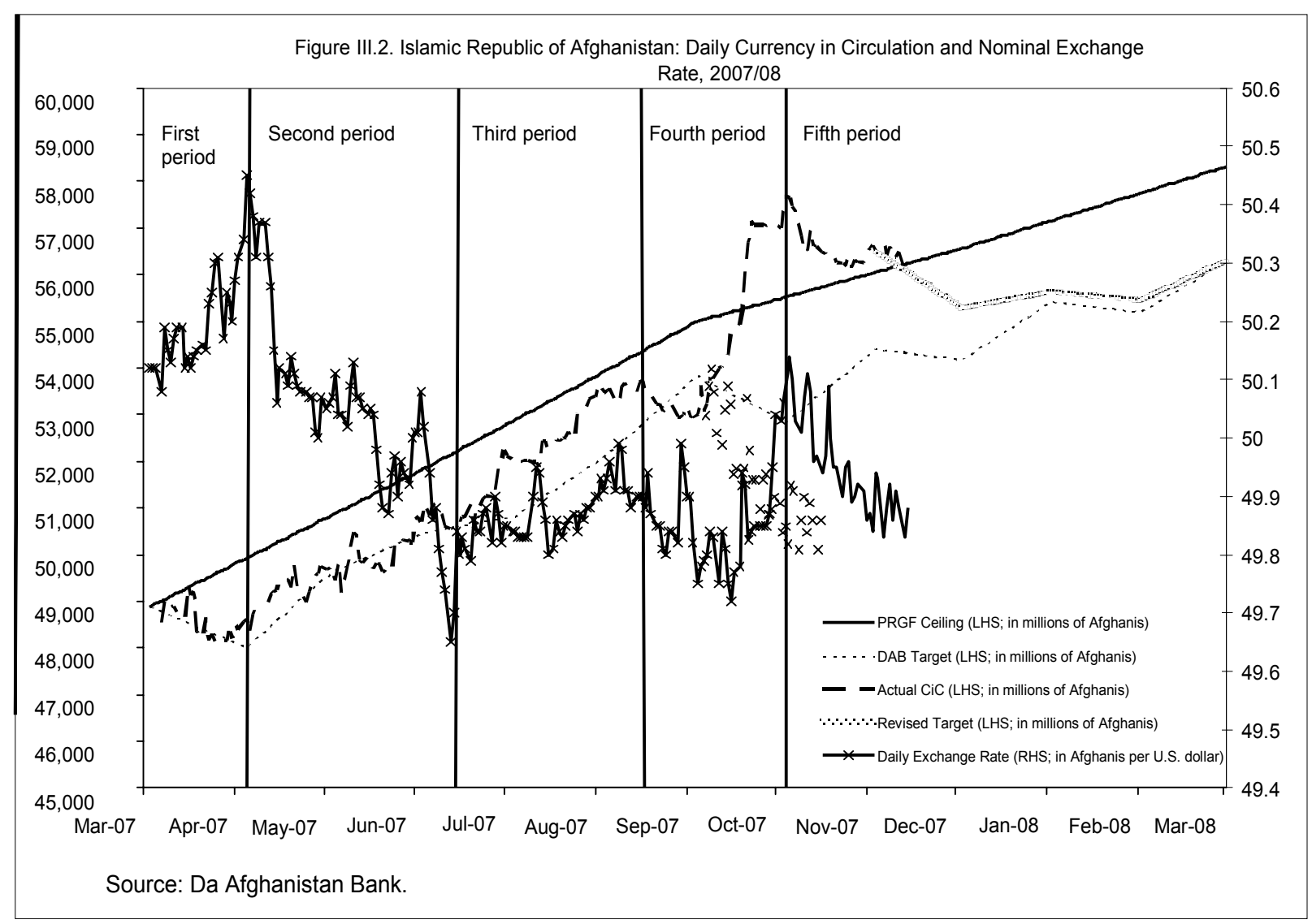

14. During the first period (March 21 to April 21, 2007) and second period (April 22 to June 28), DAB successfully kept $\mathrm{CiC}$ close to its targeted level. During the first period, DAB targeted a gradual decline in $\mathrm{CiC}$ in line with relatively low liquidity injections by the MOF (consistent with the budget cycle) and the U.S. Army. As shown in Figure III.3, the lower liquidity injections into the economy led to a reduction in the volume of U.S. dollars sold in the auctions. During the second period, DAB stepped up its interventions in the foreign exchange market to mop up liquidity due to higher spending by the MOF and the U.S. Army. The increased interventions led to a gradual appreciation of the Afghani (by 1.5 percent). While DAB's monetary policy was successful at keeping CiC close to its target, these two periods were characterized by increased daily volatility in exchange rates (in excess of DAB's target of \pm 5 basis points). 


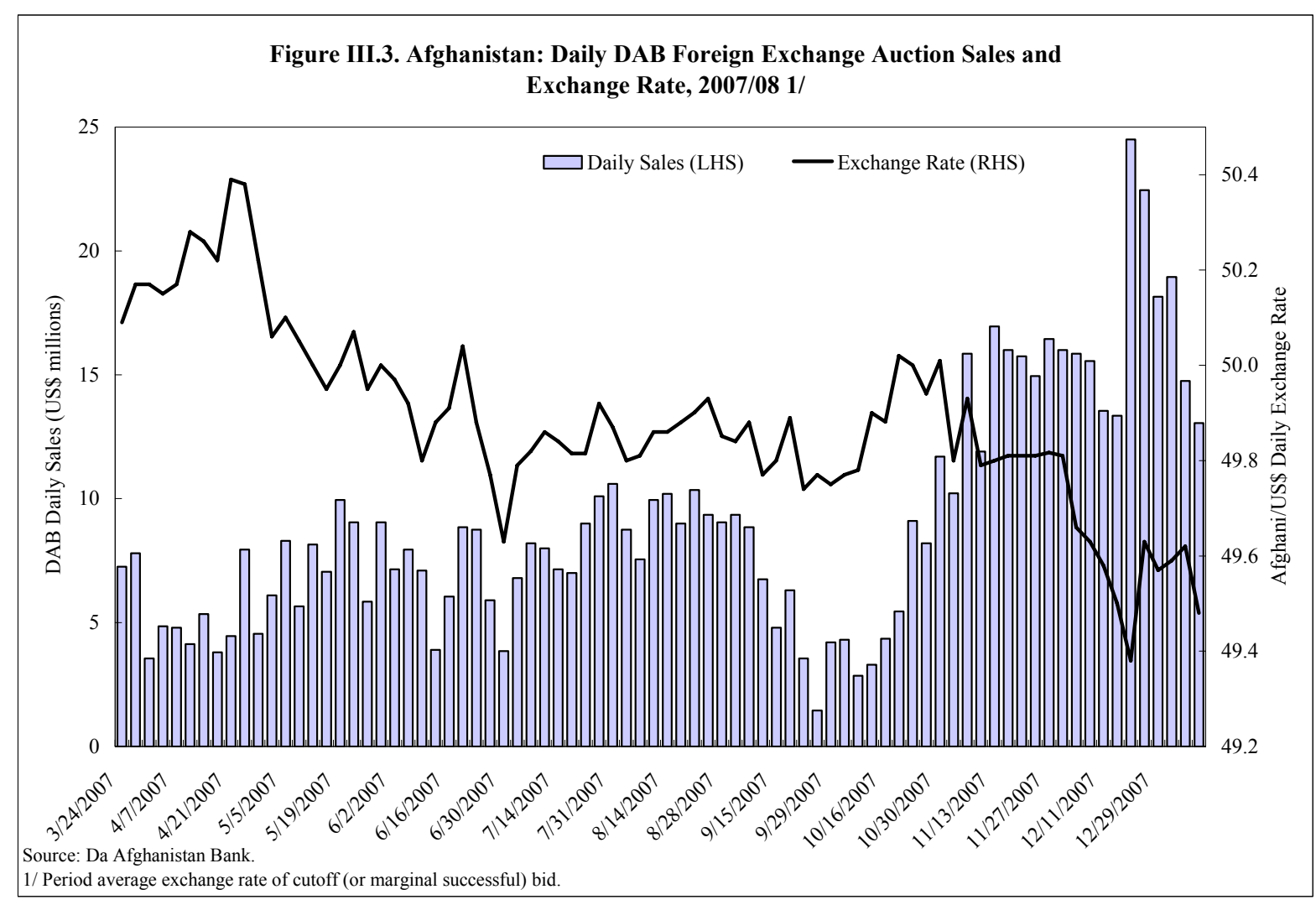

15. During the third period (June 29 to September 3), the target level for CiC was exceeded, suggesting that concerns about a nominal appreciation of the Afghani may have influenced monetary policy. The volumes of foreign exchange sold during this period were significantly below the amounts projected at the beginning of the year, despite higher than projected liquidity injections by the U.S. army. As a result, CiC exceeded DAB's target, although it remained comfortably below the program ceiling. At the same time, the appreciation of the Afghani was halted.

16. During the fourth period (September 4 to October 22), the implementation of of monetary policy was hampered by serious difficulties with liquidity management. Because of delays in shipments of Afghanis from abroad, domestic currency checks presented to DAB by the government, the U.S. Army and others could not be cashed. In an attempt to satisfy the government's demand for Afghanis, DAB increased the sale of foreign exchange, with the result that $\mathrm{CiC}$ started to fall below its target. When Afghanis did arrive, DAB was not prepared for the sudden increase in liquidity, and because it had intervened heavily to buy Afghanis for the government, did not have sufficient amounts of foreign 
currency in cash to sterilize. As a result, $\mathrm{CiC}$ surged above both its target and the implied ceiling under the program, and the nominal exchange rate depreciated by close to 1 percent. $^{6}$

\section{During the fifth period (October 22 to end-November) DAB intervened heavily} to bring CiC below the PRGF ceiling. The volume of foreign exchange sold at auctions was dramatically increased, from a yearly average of approximately US\$15 million per week, to US\$30 million per week in November, and was accompanied by a gradual appreciation of the nominal exchange rate. In addition, a new path for $\mathrm{CiC}$ was introduced to bring $\mathrm{CiC}$ back to its original target by the end of the year. The efforts of $\mathrm{DAB}$ to bring $\mathrm{CiC}$ back down to target during this period reflect its commitment to the $\mathrm{CiC}$ target over the exchange rate stabilization target when these two objectives are in conflict.

18. In sum, DAB has actively used foreign exchange auctions to smooth out volatility when this was consistent with the ceiling on $\mathrm{CiC}$ under the PRGF arrangement. There are, however, limits to the degree of flexibility associated with the deviations from the $\mathrm{CiC}$ target. On the upside, the limit to this flexibility coincides with the PRGF ceiling. On the downside, the limit is less clear, but could be interpreted as the level of $\mathrm{CiC}$ consistent with the floor on net international reserves in the program.

\section{Conclusion and Summary of Recommendations}

19. This paper discussed the current monetary policy framework in Afghanistan, reviewed its implementation, and recommended some measures to improve its effectiveness. Over the past two years substantial changes - most of them based on recommendations provided by TA from the Fund - have been made to both the instruments and the implementation of monetary policy These changes have improved substantially the ability of DAB to meet its ultimate goal of stabilizing inflation and to formalize the operational framework for monetary policy. The successful implementation of monetary policy during the first half of 2007/08 was testament to these improvements, with currency in circulation close to target, low inflation, and a broadly stable exchange rate. During this period, there was no protracted conflict between the CIC target under the PRGF-supported program and the authorities' objective of limiting exchange rate volatility.

20. Despite the improvements to the monetary policy framework that have taken place over the course of the last two years, a number of areas require the attention of the monetary authorities:

\footnotetext{
${ }^{6}$ The ceiling on $\mathrm{CiC}$ under the program applies on a quarterly basis. The deviation relative to the implied ceiling occurred after the September 21 test date, and therefore does not constitute a breach of a performance criterion under the Fund program.
} 
- DAB should work with the MOF to incorporate spending through the development budget in the liquidity forecast, and with donors and NGOs to improve the coverage of their operations.

- The volume of CNs should be increased to allow them to gradually become the primary instrument of monetary policy.

- DAB should clarify the degree of flexibility in its CiC target.

- DAB should consider the possibility of using base money as the primary operational target of monetary policy.

21. Reforms aimed at implementing these measures, some of which are being considered in the context of the PRGF-supported program, will be crucial for DAB to meet its ultimate goal of low inflation.

\section{Reference}

Agénor, Richard and Peter Montiel, (1999), Development Macroeconomics, (Princeton: University Press). 